\title{
Benefit from the aesthetic values of the line element in the work of Egyptian artist (Abd-Elwahab Abd-Elmohssien) for Evening Fashion Design by modeling on the dress-stand
}

\author{
Dr. Nermin Abd-elrahman Abd-elbassiett \\ Assistant professor in Clothes \& Textiles department \\ Faculty of home economic - Helwan university
}

\section{Abstract :-}

There are several schools in the field of the fine arts, so each fine arts artist has become looking for the style that can distinguish him from the others. This research discusses one of the distinguished fine arts (Abd-Elwahab AbdElmohssien). The researcher defined the artist, his technical view and his technical style, utilizing some of his works to make evening fashion design for the age ranging from 18-21 years old by modeling on the dress form evaluating the designs, among the specialized or the consumers to know more about the acceptable designs .

\section{Key words :-}

The aesthetical values, Line, Fashion design, The modeling on the dress form.

\section{Introduction :-}

The line is considered one of the main technical factors that use by the fine arts and fashion designer in work .

It is both the simplest and the deepest . It is also considered of the most difficult elements and more complex, if they were not used carefully, the different lines determine the general shape of the technical work. Lines are the limitations of the things that describe and link them to give the direction and the motion ,they divide the large spaces in the technical work into small pieces. line is the secret of the success for the design, the eye follows lines from right to left and up down and in all the directions. Good technical work that its lines will be linked together in harmony and each part of them will cope with the other .

Lines have a role in the visual deceit . They contribute in making the person taller or shorter, they can change dimensions of body parts, lines can play main role in changing the fashion through ages, they also determine and show the general frame of the clothes in certain period of time, before any other accurate details during this period.

Artist and fashion designer can use advantages and features of lines in the innovation of technical works, that may arise many meanings that can extend from the stability, balancing and fixation on the feelings, rush and tension, line in the design or the technical work is not limited to being the external line that can set the shapes only but it has its independent aesthetical value that may cause the development of the sense by the motion. (6-1996 page 54) 
Expression by lines in the technical work depend on a group of points including the used means in performing nature lines of the surface on which line will be drawn direction of ( horizontal, vertical or declining ) the extent of straightness, bending, the thickness of the line or its length and shortness in the technical work. The ends of the line as may be coarse, soft, quadric, rectangular, around. (3-1996 page 54)

Due to the multi schools of the recent fine art so each artist looks for the style that can distinguish him from the others. This research tackles one of the artists whom is distinguished with the fine arts technical sense (Abd-Elwahab Abd-Elmohssien) got several prizes either locally and international, he has attendance in most of the international technical exhibition inside Egypt and outside it . So the researcher found that there are rarity in the studies that analyze the technical works of the artist (Abd-Elwahab Abd-Elmohssien) as an artist whom depended on his technical view in employing lines to become dimension of technical work, the reflector of the artist's emotions and utilizing these works to be the source of quotation among the Egyptian artists for the fashion designers by modeling on the dress form .

The researcher chose to utilize the works of the artist for evening fashion design for the girls ( age ranging from 18-21 years old) to what they have of distinguished psychological feelings, quick emotions and contrasting ones .

Choosing previous artist to what is distinguished with technical style full of different emotions, and due to his care with treating the technical positions by entering inside the depth of the human being and exiting the feelings on the surface of his panel in shape of his lines .

\section{The problem in the following enquiries :-}

1- Who is the artist (Abd-Elwahab Abd-Elmohssien)?

2- What is the vision and the extent attention of the artist (Abd-Elwahab AbdElmohssien) by using the aesthetical values of the line in his works?

3- What is the extent of utilizing from the aesthetical values of the line in the works of the previous artist to design the clothes for the girls by modeling dress form?

\section{Objectives:-}

1- Studying some works of the (Abd-Elwahab Abd-Elmohssien) and recognizing his technical attitude.

2- Analyzing the aesthetical values of the line in some picture of the previous artist .

3- Utilizing the aesthetical values of the line in the works of the artist (AbdElwahab Abd-Elmohssien) to design the clothes of the girls in the age of 18-21 by modeling dress form.

\section{Importance:-}

The importance of the research is to high light the artist distinguished in the photography field and gaining several awards whom is artist (Abd-Elwahab 
Abd-Elmohssien) recognizing his technical style through the analyses of the aesthetical values of the line in some of his works and utilizing them designing the clothes of the girls .

Also the importance of this research is due to enriching the Arab library with specialized study in this field and utilizing them in the field of the fine arts to produce a fashion that has its distinguished sign for the fine arts in our recent society .

\section{Limitation :-}

1- Studying the aesthetical values of the line in some works of the fine arts (AbdElwahab Abd-Elmohssien).

2- Recognizing the technical and shaping style of the previous fine arts.

3- Utilizing the aesthetical values of the line in the works of the artist to design clothes for the girls of ages ranging from 18-21 by modeling on dress form .

\section{Methodology :-}

This research uses the descriptive methodology to analyze the works of the fine arts and the methodology application to design a group of clothes affected by the style of the artist (Abd-Elwahab Abd-Elmohssien).

\section{Terms of the methodology :-}

\section{Line :-}

It is the direction result from the movement of a point in certain path the line determines the external edge of the drawn surface as it sets the place of meeting or the intersection of the 2 surfaces or two levels together (8-1982-p13).

\section{Previous studies :-}

1- Samier Mahmoud Abd-Elfadiel :

A photographer For The artistical groups in Egypt During The 40th Master Degree 1977.

This study included the stages of the development of the fine arts in Egypt during the ages passing by the wars the rebellions that Egypt passed . and affected on the fine arts movement. Also the researcher discussed the early pioneers in the field of the fine arts in Egypt and their role in enriching the field of arts.

\section{2- Mohamed Ibrahiem Mohamed :}

The effect of the modern technical schools in the west on the works of some pioneers in the Egyptian photography analytical study and comparative one by applying on the printed table clothes and the clothes doctorate degree in 2003.

This research included some of modern art schools like the expressive. The seraglio, the degrading and analyses some works of artists in the west and the extent of their effect on the Egyptian photographers then innovating the designs that can be suitable for printing on the clothes or the table clothes . 


\section{3- Mohamed Saliem :}

\section{An entrance for the recent fine arts- master Degree 1993.}

In which the researcher discussed the fine arts during the different ages with presenting some schools of the modern art and the works of to some Egyptian pioneer who were affected of these schools .

The researcher utilized from these studies in recognizing the historical development for the fine arts movement in Egypt, and the modern technical schools in the west and their effect on the Egyptian artists recognizing the style of technical analyses for the pictures of the artists, and how to know the technical vision of the fine arts and the technical criticism for these pictures knowing how to reach to the definition of the artist style his technical work through the analyses of his lines, colors , shapes in his drawings.

\section{Background about the Artist :-}

(Abd-Elwahab Abd-Elmohssien) was born in one of the Dakhalya villages in 1951, he loved drawing since his early childhood, he attended the free department in the faculty of the fine arts " Alexandria university" in 1976 he studied in the "Graphic art" through distinguished artists . He discover his technical character through the western technical school that affected on the technical artistically movement in Egypt like the expressive" Cubism" and "Abstractionism" school, he got the higher studies diploma in the "Graphic art" in 1986 then he got the master degree in the photographing in the faculty of fine arts Helwan university in 1993 then he got the doctorate degree in the philosophy from the fine arts faculty of Helwan university in 1998 then he joined the fine arts union and became a permanent member in it he also participated in the group of the artists and writing in "Cairo Atille", he is also a member among the members of the international scripture SMTS in Poland (5-2003 page 182).

The artist (Abd-Elwahab Abd-Elmohssien) he specialized in the fine arts in the public culture sector. He was a teacher for the designs in the art academy and the design in higher institute for the applied arts . He also established the department of the photographing in the university of "Elzeitouna" in Jordan in 2000-2004.

He participated in several international exhibitions individual and group inside and outside Egypt since 1988. he got several awards local since 1977 as he got the first prize in the graphic from the supreme council of youth, then he got the first prize for the graphic from the national center of the fine arts for two successive years 1987-1988.

$\mathrm{He}$ also got the second rating positions in the competition of the" Nile belonging" to the national center for the fine arts in 1992 then he got the first prize in the national "Benally" of port said in 1993 and the first prize in the autumn exhibition in 1998.

The artist (Abd-Elwahab Abd-Elmohssien) got several international awards in Alexandria "Benally" in 1994 and honorable from the second award" Ttrinally " for the graphic in Cairo in 1997 then the third bin ally graphic in 2000. 


\section{The fine arts vision of the artist (Abd-Elwahab Abd-Elmohssien):}

The works of the artist passed through several stages including the degrading "Graphic" recording the public life in symbols, then photographing the natural views with degrading view. Then the stage of diving within the self inside the human being psychology, and photographing . The technical subjects by different decorated lines of the rhythms to express the view using the warm colors sometimes and the cold colors other times, to deliver the meaning to the viewer the artist (Abd-Elwahab Abd-Elmohssien) is always caring with his innovative vision that inspired by the Egyptian environment and the Egyptian heritage , he cared with merging and constructing, colors, lines to complete each other, he concentrated linear exceeding in regular shape in most of his works. He deliberately spread linear styles in different directions to add the psychological stability on the technical taster of his panel.

\section{Technical Style Of The Artist (Abd-Elwahab Abd-Elmohssien) :}

1- Using the linear aesthetical values :

He care with line as an fine arts element in the most of his technical works and used it to be the main dimension in his drawings, he used the alternative line of the shadows in his other works (panel 1).

2- Merging between the intensive color and line:

As the artist used the exceeding linear in tensively as he employed the interlaped lines, so some of his works can deliver the meaning that the artist intended, he used also the intensive color in different degrees, the intensivity of the line and the color led to the creation of dramatic weight in his pictures (Abd-Elwahab Abd-Elmohssien) in (panel 2 ).

3- His tendency to the gradation :

The artist has used the shapes and the places of the nature then transferring them into harmonized group completely of lines and colors to make them far away from the real shape contending by taking the core of the shape and the meaning that indicates on it, then phrasing its in anew technical way. He uses the neighboring horizontal lines besides each other then he uses the interlaped lines or amixture of them to produce sensitive expressions and of higher taste ( panel 3).

4- Using the white and the black color :

(Abd-Elwahab Abd-Elmohssien) cared with using the two colors of white and black in some of his technical works. ( panel 1).

Analyzing some of the technical works for the artist (Abd-Elwahab AbdElmohssien) :

\section{Name of painting ( The shadow ) :-}

The artist could express his feelings in this panel by the degrading lines and in distinguished style so we can find that he used the lines repeatedly, and in different lengths he could employ the color spaces harmony, and in clear line as if light color spots and dark ones that can separate each line from the other to 
give a shadow and elevated rhythm, that the tasteful eye looks for then he suddenly surprises us by a block of the interlaped lines and the intersectional ones to give the sense of noisy that is lovable and the rebellion against the regular rhythm of the lines, the degree of intensifying the lines served in different directions to make continual motion helped by the brown spots " panel 4".

\section{Name of painting ( The lake ) :-}

(Abd-Elwahab Abd-Elmohssien) has translated his feeling with the lake into moving linear effects. Values and colors that can reflect its degrading vision depending on his internal feeling with the value of the block and its relation with the vacuum surrounding it, he divided this block into a group of successive lines in horizontal shape and declining lines . Sometimes he interlaped treated the moving surface of the lake by merging, the rose color with the blue which are the colors that are lovable by the people and he could show the movement of the lake in drawing geometrical shapes, that are outlined to express the movement of the fish inside the lake, he asserted it by the declining lines and concentrated in the orange color pots to pull by them the attention of the eye towards the motion, he also used the green color to show the life inside the lake. $\mathrm{He}$ asserted it by the declining thick lines that are swinging in different direction inside it " panel 5".

3. Name of painting ( The peace ) :-

The artist (Abd-Elwahab Abd-Elmohssien) expressed his view of peace by a group of the degrading shapes of birds, and oil leaves he used the intensive color for the degrees of the brown color and treated in horizontal shape neighboring regularly in the center of panel, he asserted these lines by widening the distance between each line and what is next to it to attract the eye of the viewer and to feel with purity and peace the artist contributed in the weight of the dramatically motion in the picture by merging. The several lines randomly at the edges of the technical work to help in moving the eye behind the motion of this line and feeling with joy and pleasure so we can find the artist has succeeded to deliver to the taster the harmony between the lines in the background of the panel and the color weight, that is spread in the horizontal lines that are concentrated in the core of the picture to express the stability of the self with feeling of peace " panel 6".

\section{Name of painting ( deploring in the depth ):-}

It is of the important works that reflects the stability of the word of the artist (Abd-Elwahab Abd-Elmohssien) and the maturity of his symbols and his technical feelings in the structive treatment to the positions or the places by using the lines and the colors as the style of artist appeared in expressing the depth of the human being self in his panel by showing the linear noisy and the crowd ness of the colors and the motional rhythms that are elevating and are hit strongly in several places of the panel and in another parts as we can find calmness and tranquility in the lines besides the harmony in the colors. In the 
background then the technical sense elevates again so the taster will be hit by a block of the interrlaped limes and the spots of colors to find himself withdrawn into sinking into thick lines in around shape, to reach once again to the point of the beginning in the picture the sense will remain among the viewer who breathes heavily behind the movement of the technical work lines that he wants to deliver to us in expressing of the oneself and its feelings and senses of contrast continually " panel 7 ".

\section{Name of painting ( Towards the unknown ) :-}

The artist depended on expressing his technical senses in this picture on the sculpture style, as he depicts his dimensional character stone statute or wooden one that is silent without movement, in which the actual details disappear and all the differences melt. So it will appear like silent block on its features appear the wariness and fearing the unknown. We can find that the artist has drawn a degrading shape for a human being surrounded with the darkness and the dust he cannot do anything except to hide in one corner and restrict himself in a limited circle of the light, so he cannot see any thing and that his willingness van not expand to more than this space surrounding him. The artist asserted this technical value with as group of the interrupted and stacked lines in the depth of the picture and showing the black color to assure the meaning of the fear for the man from the unknown "panel 8".

\section{Name of painting ( The song of the morning ) :-}

In this technical work dominates the linear the color and the surface calmness as the artist left wide space of vacuum in large part of the picture. He used the bright yellow color to express the beginning of the day, he distributed on the surface of the picture lines of different attitudes to represent the movement and the activity that felt by the human being at the beginning of anew day . The artist has added a space for the grey color at the edge of picture abd linked it with a space of the yellow color in a group of the lines and the regulated shadows and besides each others to represent the finishing of the night and the beginning of the day in calmness to arouse in one's self the feelings of the airs for the breeze of the morning that is fresh with the night of the dawn " panel 9".

\section{Results and discussion :-}

\section{First " answer for the research enquiry" :}

\section{Regarding the first enquiry :}

Through the study it became possible to define the artist (Abd-Elwahab AbdElmohssien) defining his technical achievements and the scientific degrees and the awards that he got during the different periods $\mathrm{m}$

\section{Regarding the second enquiry :}

The researcher showed the technical vision for the fine arts artist through the analyses of some of his distinguished works and presenting the aesthetical values of the lines that we employed by the artist. 
The researcher showed the aesthetical values of the lines in the works of the artist through the analyses of some of these works that are represented in the extent of the linkage and the harmony between the neighboring and interlapedlines by distinguished motional linear rhythm

\section{Regarding the third enquiry:}

The researcher drew a group of the designs and presented them to some specialized in the field of the clothes to make more of the designs acceptable then she applied 5 designs on the Mannequin meanwhile showing the style of execution and the used materials the source of quotation.

\section{Secondly " results of the applied research" :}

\section{Executing the material of apparent effect on the different textiles or clothes:}

As the researcher used a material of apparent effect to give impression on the neighboring lines as it is in the pictures of the artist with the existence of color background of these lines. she used for this reason satin clothes and the industrial wool, she determined the required width of the material $\mathrm{m}$ then she needled thee piece by declining lines and leaving a space between each line on the other on the account of the design then she separated by the scissor a line half the space between each line and what is next to it without separating the lower class and the last one by the clothes then the researcher combed the textile piece by thick brush in the adversary direction of the wabeir several times to get the required effect, lastly to employ the textile clothes inside the suggested design and quota Ted from the works of the artist .

\section{Suggested designs :}

The researcher designed a group of the clothes to the girls of age 18-21 that affected the works of the (Abd-Elwahab Abd-Elmohssien) he presented these designs to a group of the specialized in the field of the clothes and a group of the consumers also designing the questionnaire form and the extent of its acceptance and knowing more of the designs to be made as they are acceptable the researcher did or made a group of these suggested designs .

The following are the procedures of execution or application of these designs and modeling on dress form .

\section{Applied design (1):}

Material : Stain plain synthetic wool .

Colors : The light brown color that bending to the orange .

\section{Style of application :}

1. The researcher used textile material of apparent effect to shape the part of the chest as it was brought 3 classless of the stain with the dimension of $30 X 30$ then she made the needle works with declining lines till the end of the stain square then cutting the textile between the lines of the needling and leaving the last class of the textile without cutting then 
combing the textile with a brush of wire in the opposite direction then the resulted material will be of distinguished motional effect .

2. Shaping the chest by pulling the applied material on both sides of the mannequin then shaping the rest of the dress and concentrating the lines with the movement of flowing insidal in the front part of dress to flow gradually in harmonically shape .

\section{Aesthetical values for the line in the applied design :}

The source of quotation is ( panel 6 ) for the (Abd-Elwahab Abd-Elmohssien) as it was used the apparent lines in the corsage synthesis material that was applied by the researcher to give linear effects that can arouse the apparent and the hidden feeling as it is in the panel, then was applied soft motional lines in the skirt and in an opposite direction against the direction of the movement of the lines in the corsage to make a kind of motional contrast for the line that is lovable to the human being.

\section{Applied design (2):}

Materials : The colored chiffon with the orange and violet degrees - the stain wool, lace textile.

Colors : The violet the orange the light orange .

\section{Style of application :}

1- The researcher has used an apparent material of 3 type of stain textiles or clothes the chiffon and the till and giving a declining linear effects with the sizes of $(30 \times 30)$ and making declining lines then cutting between these needles and leaving the last class the lower of the wabari textile without cutting then combing the material in the opposite directions.

2- Shaping the chest of the dress that was applied previously then shaping the other corsage with the chiffon textile and giving declining linear effects to show and asserting the aesthetical value of the moving declining lines .

3- Then adding another piece of textile of the wabari textile or material that was applied by the researcher with the orange color in the side of the dress to make color rhythm and apparent linear effect through the contrast between the soft touch of the chiffon then next to it directly the apparent effect of the applied material previously.

4- Then shaping skirt of the address by insidal lovable by the lines and the different soft materials in its colors touches to show its esthetical values of the design.

\section{Aesthetical values of the line in the applied design :}

The source of quotation ( panel 4 ) for the artist (Abd-Elwahab AbdElmohssien) as it was employed the declining lines and the harmonized bending lines inits colors, its lengths, for the gradation of the tasteful eyes in the successive motion of the lines without any violent rhythm also the wabari material that was applied by the researcher served in giving the sense of the 
apparent lines and the successive ones as it is in ( panel 4) to express the credibility of the quotation for the picture of the artist .

\section{Applied design (3):}

Materials: Stain - Chiffon

Colors: The light violet - the rose and the stripped yellow .

Style of applying :

1- Making from pile textile material by the rose color and the light violet needling the lines with the dimension of $1 \mathrm{~mm}$ from each line.

2- Shaping the upper half of the design with the textile material of apparent effect to give linear effects that looks like drape and in a declining shape, then putting apiece of clothes and another piece of fibers with the violet color to complete the corsage, the direction of the lines of them must be in another direction to give the linear rhythm to the design

3- Shaping the lower half of the model insidal of the clothes or the textile $\mathrm{s}$ freely and concentrating on some declining lines on the side of the mannequin to have different lengths in the address.

\section{Aesthetical values for the line in the applied design :}

The place of quotation ( panel 11) the artist (Abd-Elwahab Abd-Elmohssien) as the neighboring lines in the apparent material led to emotional linearrhytm regulated that can be elevated as a result to the existence of a spot of colors with declining lines on the adverted direction and that will lead the insidal of the chiffon clothes with soft lines and slightly under the model to create akind of lovable rhythm for all these lines.

\section{Applied design (4):}

Materials : Stripped wool clothes or textile fiascoes .

Colors : The light brown and the dark brown the stripped beige with the brown . Style of application :

1- Using the material of the blasé of the stripped wool to give the impression of the apparent and the low ,

2- Shaping the second lower half of the dress from the material of the brown fiascoes.

3- Shaping the address of from the stripped wool and making some bendings or kasrat of radiation irregular on the side of the address.

4- Shaping irregular flower ion the shoulder of the address.

\section{Aesthetical values of the lines in the applied designs :}

The source of quotation ( panel 2), using the pleated lines led to the feeling with exceeding the lines of apparent effect and the low one as it is in the picture of the artist, also using the degrees of the brown color led to appearing the motion rhythm for the line and the color together, it must be put a color space with round lines represented in the shape of arose on the shoulder of the design which is quitted from the shape of the circle in the picture of thirstiest . 


\section{Applied design (5):}

Materials : The colored till textile .

Colors : The light rose and the dark the milky, the light green .

Style of applying :

1- Shaping the chest of the korsag on the shape of declining kasrats and irregular ones.

2- Shaping a wide skirt with belated on the side of the address .

\section{Aesthetical values in the applied design :}

The source of quotations is ( panel 5 ) as it was deployed the neighboring lines of the rose color and the blue color on the shape of successive kasrats in the address and in an irregular shape to make akind of linear rhythm .
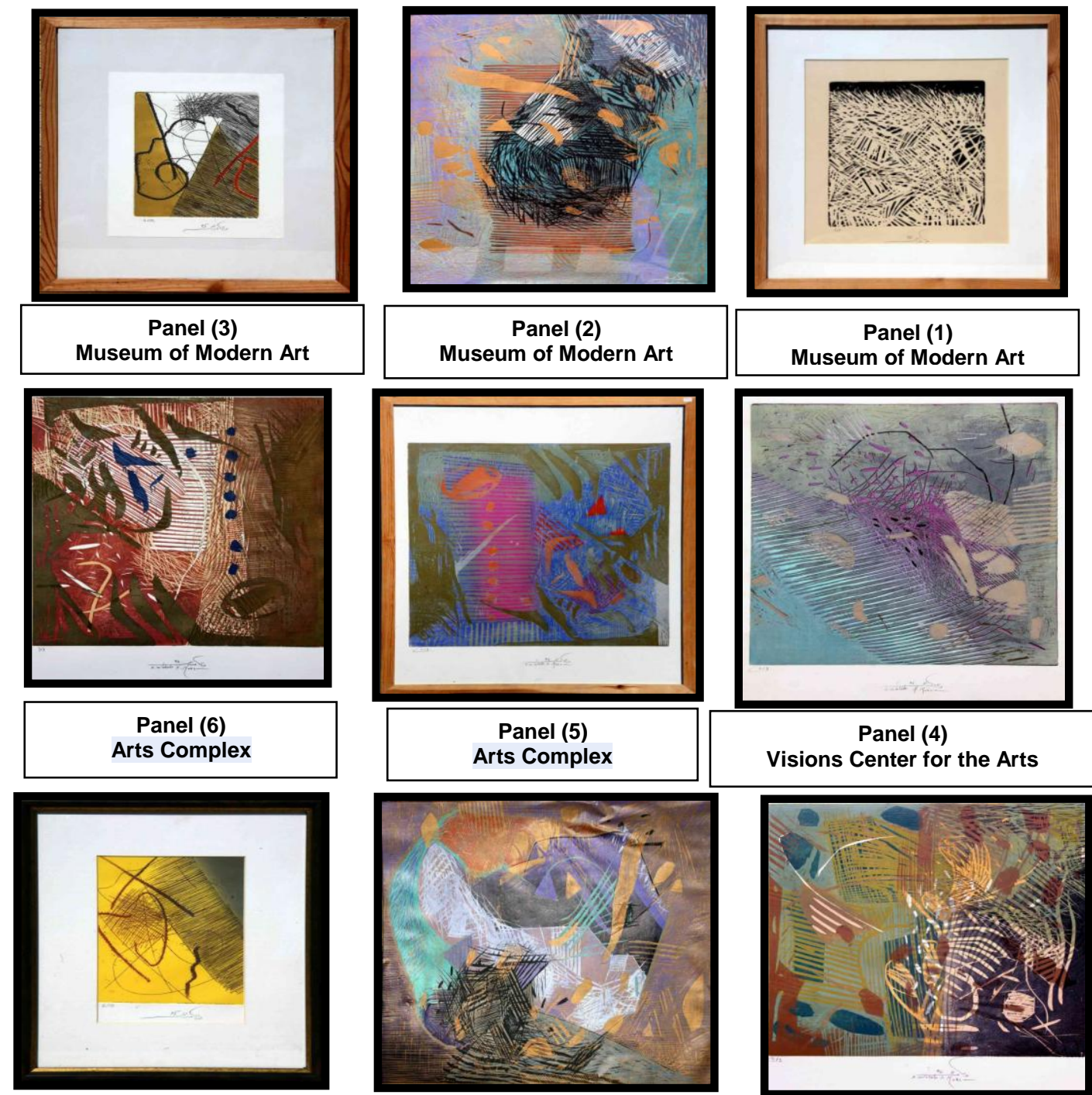

Panel (9)

Museum of Modern Art

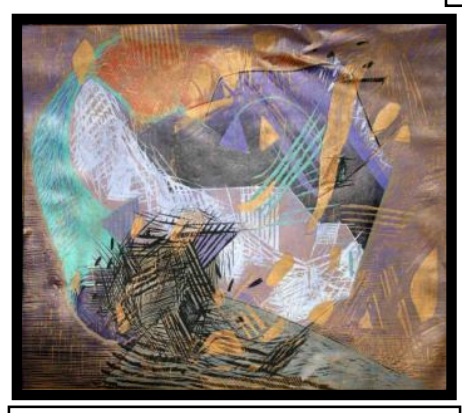

Panel (8)

Museum of Modern Art

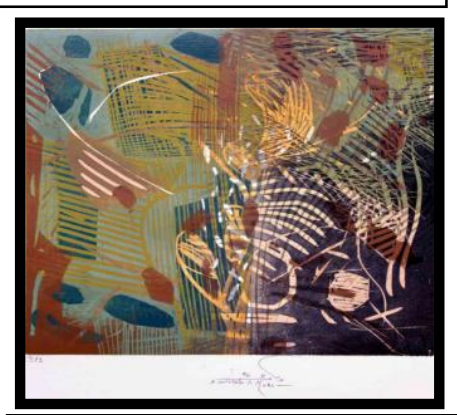

Panel (7)

Museum of Modern Art 


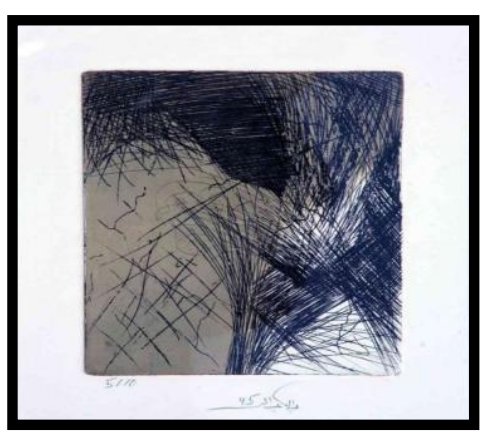

Panel (12)

Cairo Atelier

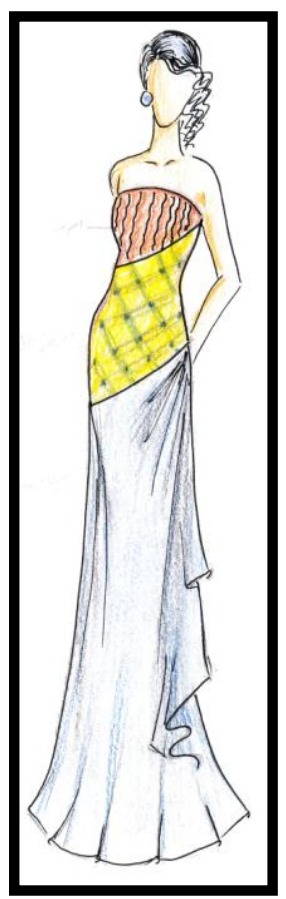

Design proposal (3) The source of the quotation Panel 11

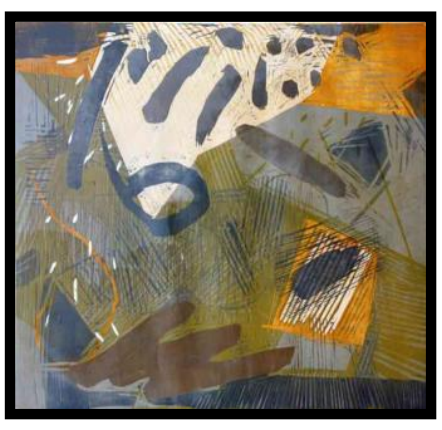

Panel (11)

Cairo Atelier
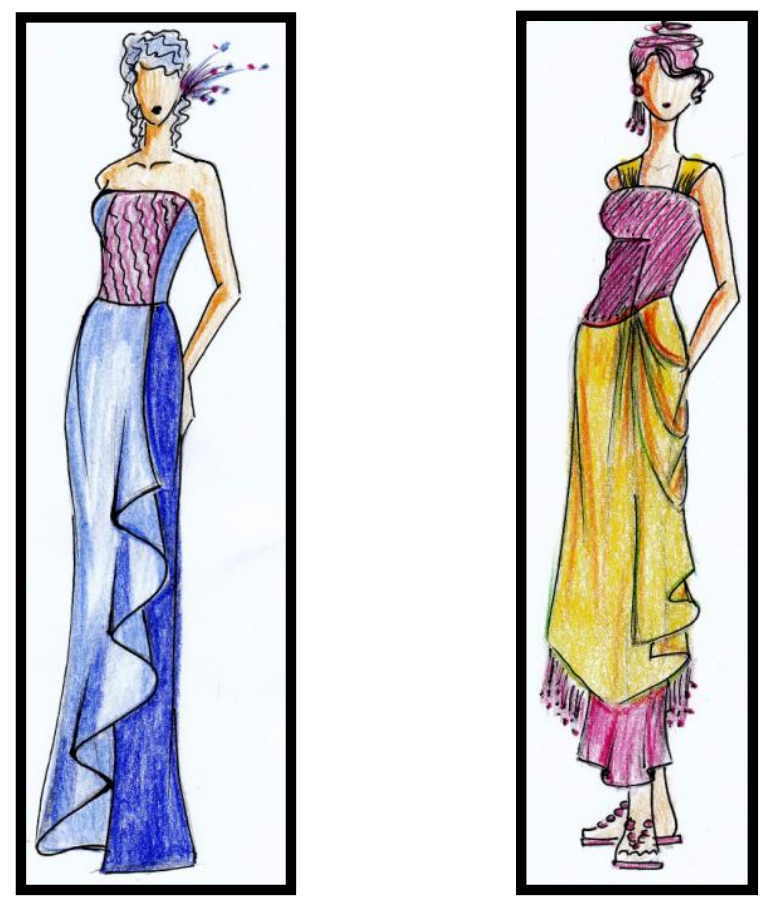

Panel (10)

Museum of Modern Art

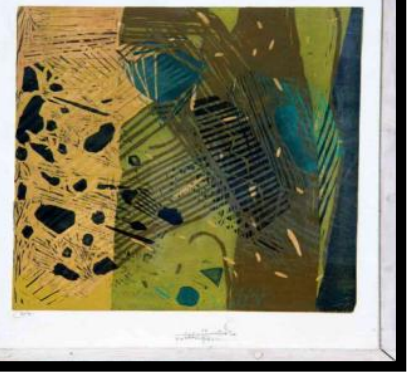



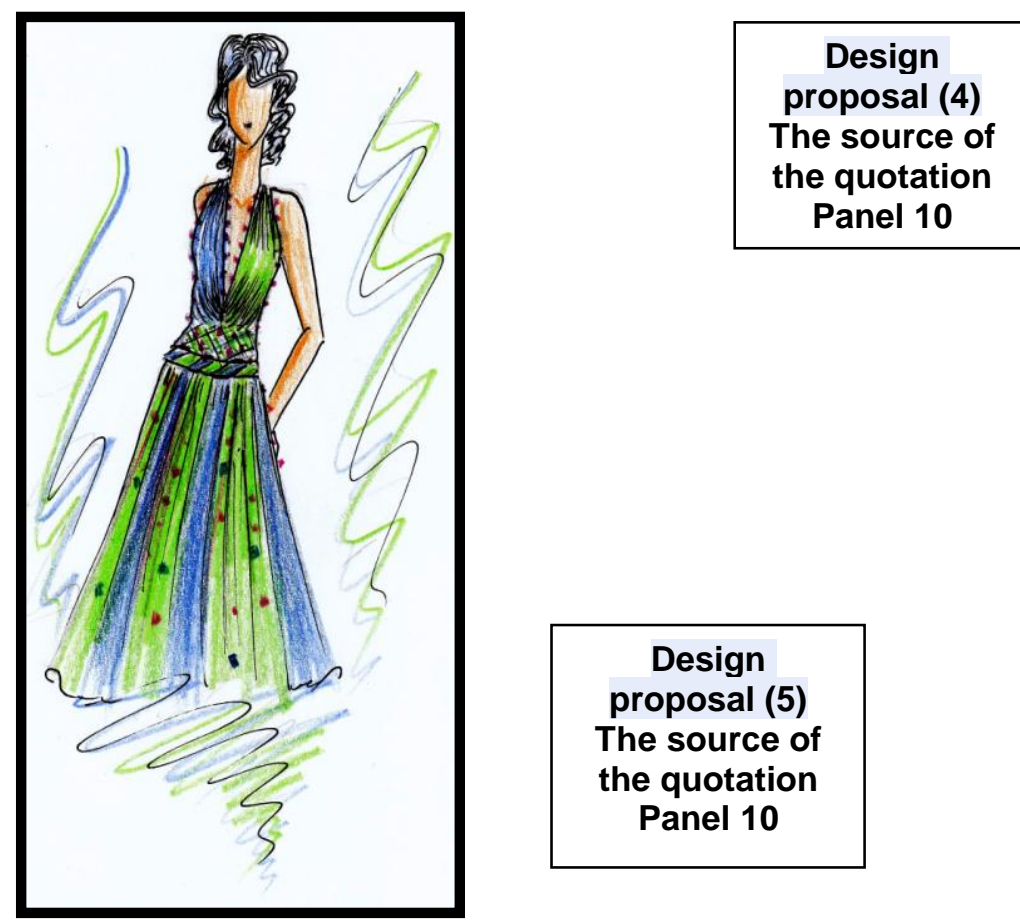

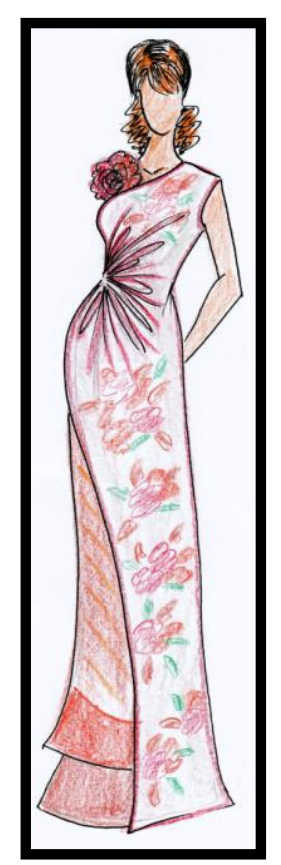

Design proposal (8) The source of the quotation Panel 2
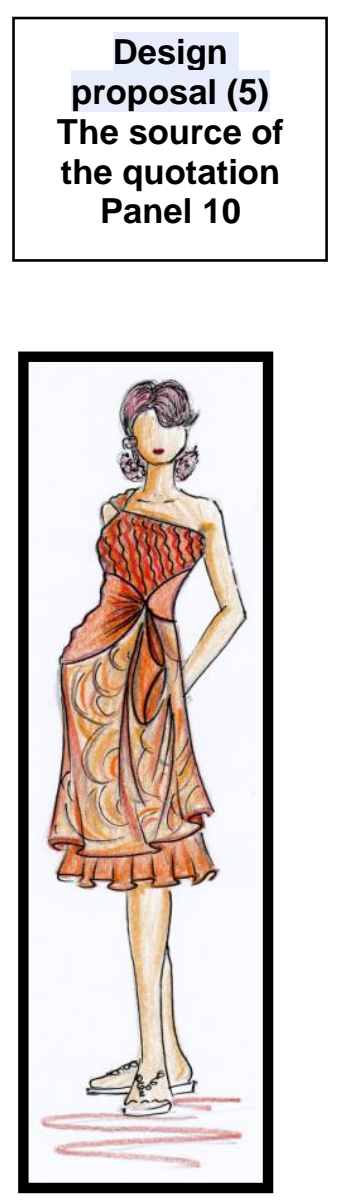

Design proposal (7) The source of the quotation Panel 6
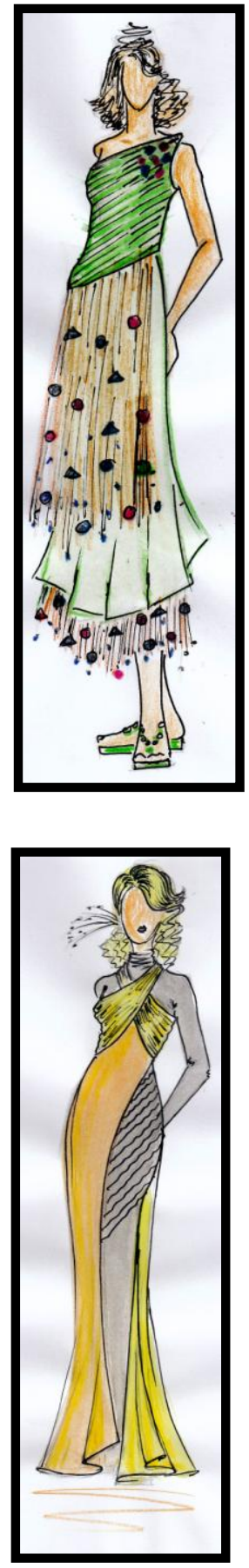

Design proposal (6) The source of the quotation Panel 9 

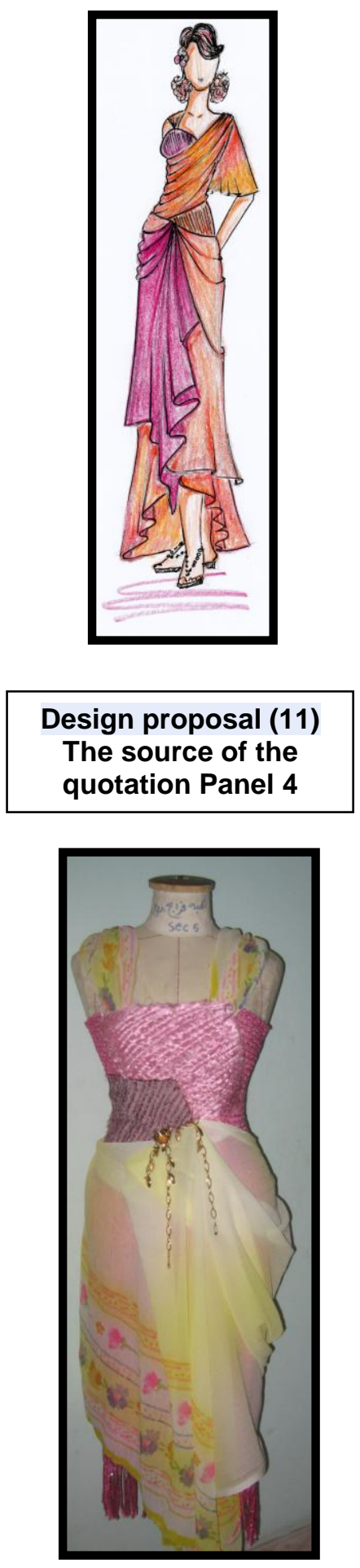

Port design (3)
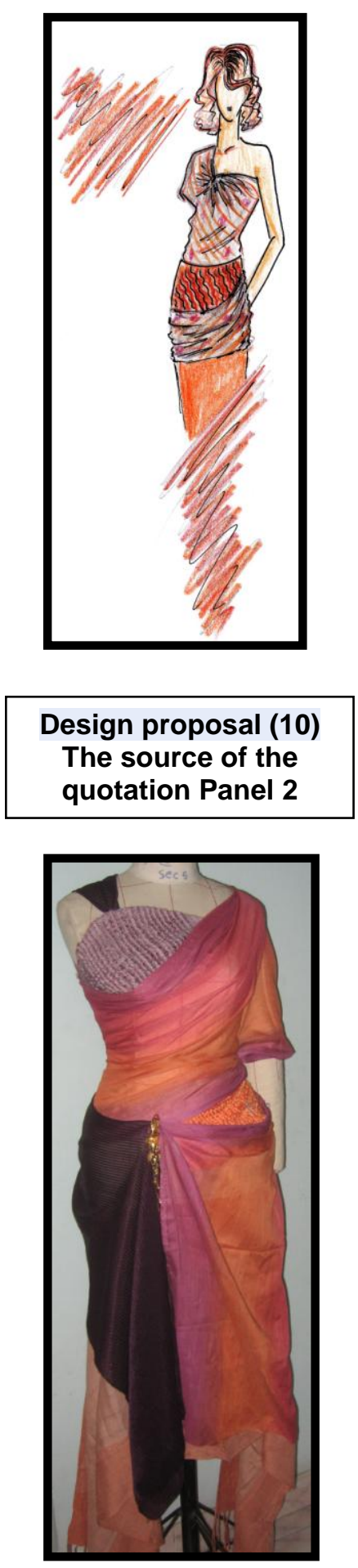

Port design (2)
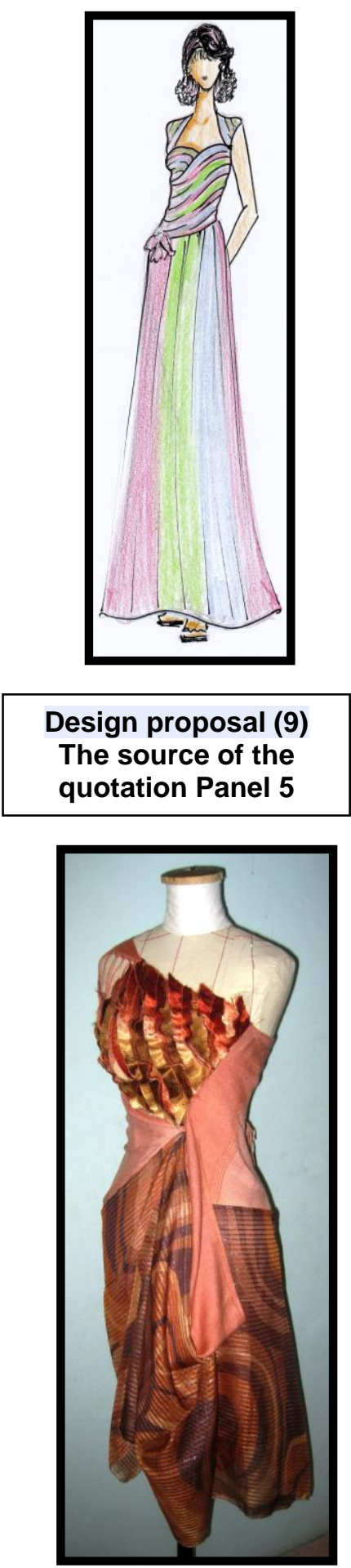

Port design (1) 


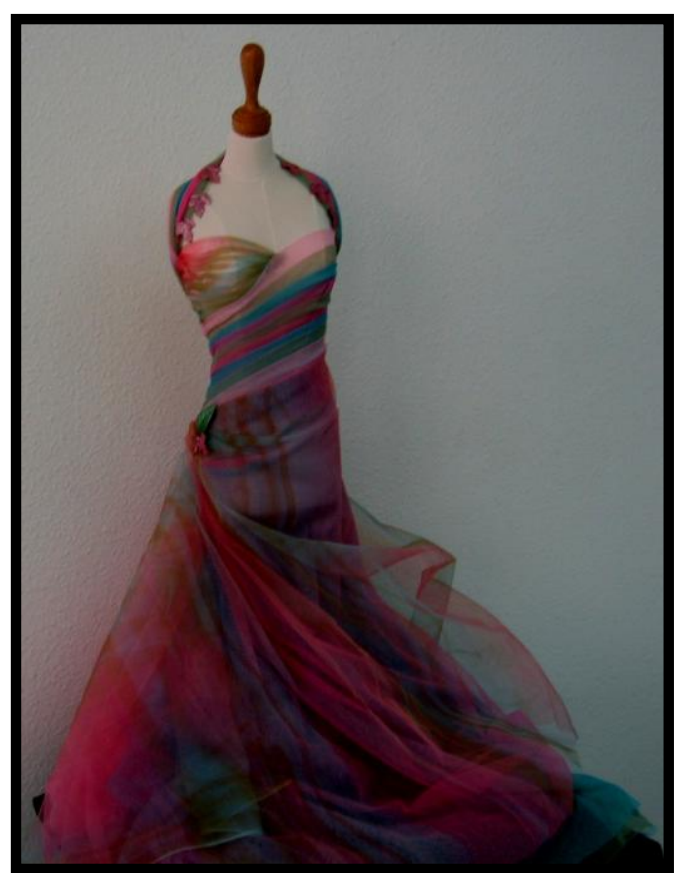

Port design (5)

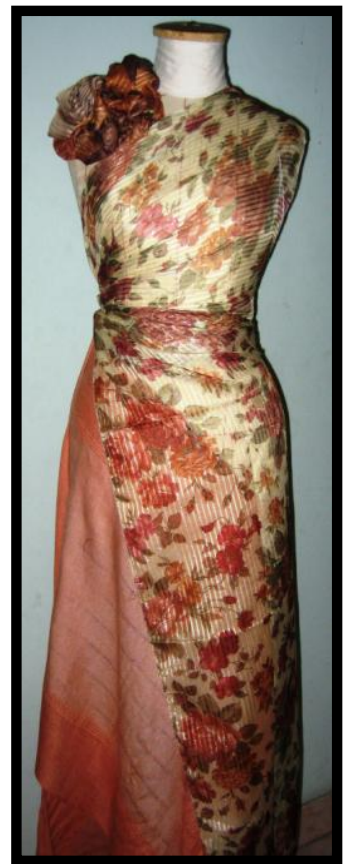

Port design (4)

The number of professional arbitrators are (9), number of producers are (7) and The consumer are (14) .

The questionnaire for evaluating the suggested designs

( It is affiliated to those who are specialized and to the producers )

\begin{tabular}{|l|l|l|l|l|l|}
\hline The questionnaire elements & $\begin{array}{c}\text { I agree } \\
\text { strongly }\end{array}$ & $\begin{array}{c}\text { I } \\
\text { agree }\end{array}$ & $\begin{array}{c}\text { I agree } \\
\text { some } \\
\text { what }\end{array}$ & $\begin{array}{c}\text { I don't } \\
\text { agree }\end{array}$ & $\begin{array}{c}\text { I don't } \\
\text { agree at } \\
\text { all }\end{array}$ \\
\hline $\begin{array}{l}\text { It shows the design for some } \\
\text { traits of the fine arts bart. }\end{array}$ & & & & & \\
\hline $\begin{array}{l}\text { It copes with the design and the } \\
\text { style of the applied shape. }\end{array}$ & & & & \\
\hline $\begin{array}{l}\text { The line has its main role of } \\
\text { aesthetical in the design. }\end{array}$ & & & & \\
\hline $\begin{array}{l}\text { It copes with the type of the } \\
\text { textile and the design . }\end{array}$ & & & & \\
\hline $\begin{array}{l}\text { The design made some kind of } \\
\text { unity between its basic } \\
\text { elements the line the material } \\
\text { and the shape. }\end{array}$ & & & & \\
\hline $\begin{array}{l}\text { The design can be suitable to } \\
\text { be a product that can be applied }\end{array}$ & & & & \\
\hline
\end{tabular}




\begin{tabular}{|l|l|l|l|l|l|}
\hline The questionnaire elements & $\begin{array}{c}\text { I agree } \\
\text { strongly }\end{array}$ & $\begin{array}{c}\text { I } \\
\text { agree }\end{array}$ & $\begin{array}{c}\text { I agree } \\
\text { some } \\
\text { what }\end{array}$ & $\begin{array}{c}\text { I don't } \\
\text { agree }\end{array}$ & $\begin{array}{c}\text { I don't } \\
\text { agree at } \\
\text { all }\end{array}$ \\
\hline and marketed. & & & & & \\
\hline $\begin{array}{l}\text { The design achieves a type of } \\
\text { distinction and originality. }\end{array}$ & & & & & \\
\hline $\begin{array}{l}\text { The design applies the } \\
\text { innovation in the field of } \\
\text { designing the clothes . }\end{array}$ & & & & & \\
\hline $\begin{array}{l}\text { The design is suitable for the } \\
\text { afternoon period . }\end{array}$ & & & & & \\
\hline $\begin{array}{l}\text { The design is suitable for the } \\
\text { girl of } 18-21 \text { years old . can suit }\end{array}$ & & & & & \\
\hline $\begin{array}{l}\text { The suggested design can } \\
\text { the sizes of } 38-42 .\end{array}$ & & & & \\
\hline
\end{tabular}

The questionnaire for evaluating the suggested designs ( It is for the consumers )

\begin{tabular}{|l|l|l|l|l|l|}
\hline \multicolumn{1}{|c|}{ The question are elements } & $\begin{array}{c}\text { I agree } \\
\text { strongly }\end{array}$ & $\begin{array}{c}\text { I } \\
\text { agree }\end{array}$ & $\begin{array}{c}\text { I agree } \\
\text { some what }\end{array}$ & $\begin{array}{c}\text { I don't } \\
\text { agree }\end{array}$ & $\begin{array}{c}\text { I don't } \\
\text { agree at } \\
\text { all }\end{array}$ \\
\hline $\begin{array}{l}\text { It suits the design of the } \\
\text { afternoon. }\end{array}$ & & & & & \\
\hline $\begin{array}{l}\text { The design suits the girl in the } \\
\text { age of } 18-21 .\end{array}$ & & & & & \\
\hline $\begin{array}{l}\text { The textile suits the trends of } \\
\text { the fashion. }\end{array}$ & & & & & \\
\hline $\begin{array}{l}\text { The suggested designs suit the } \\
\text { sizes of 38-42. }\end{array}$ & & & & & \\
\hline $\begin{array}{l}\text { The design agrees with the } \\
\text { personnel taste. }\end{array}$ & & & & & \\
\hline $\begin{array}{l}\text { It is possible to buy the design } \\
\text { and wear it. }\end{array}$ & & & & & \\
\hline $\begin{array}{l}\text { It gives the linear variation that } \\
\text { distinguishes the line, }\end{array}$ & & & & & \\
\hline $\begin{array}{l}\text { The suggested design is } \\
\text { considered as innovation in the } \\
\text { field of the clothes . }\end{array}$ & & & & & \\
\hline $\begin{array}{l}\text { I like to have the design that } \\
\text { expresses the art of therapy. }\end{array}$ & & & & & \\
\hline $\begin{array}{l}\text { It is possible to war the design } \\
\text { if it was applied among another } \\
\text { group of colors . }\end{array}$ & & & & & \\
\hline
\end{tabular}



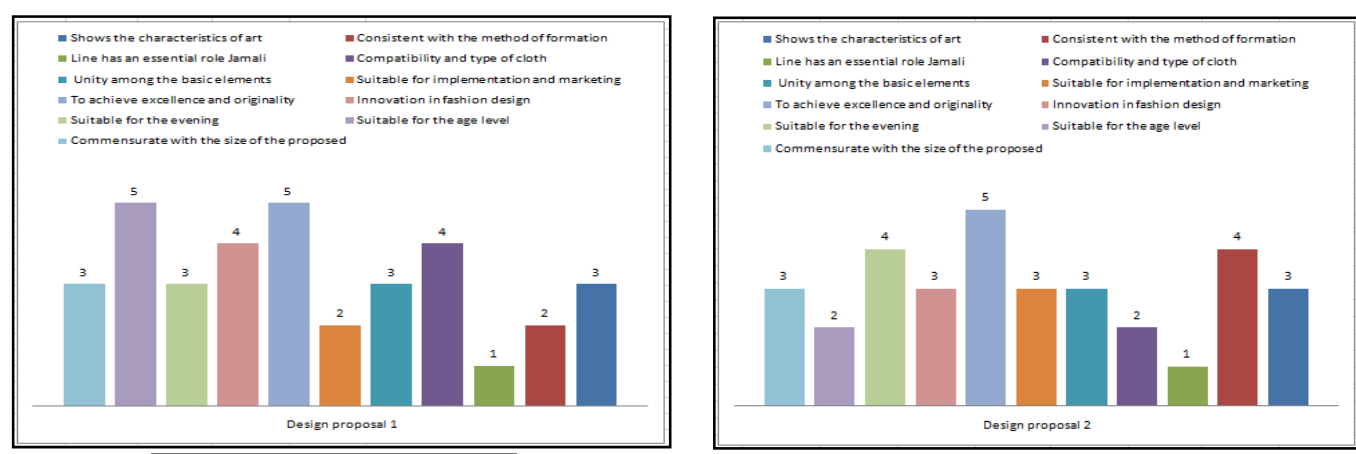

Figure (1)
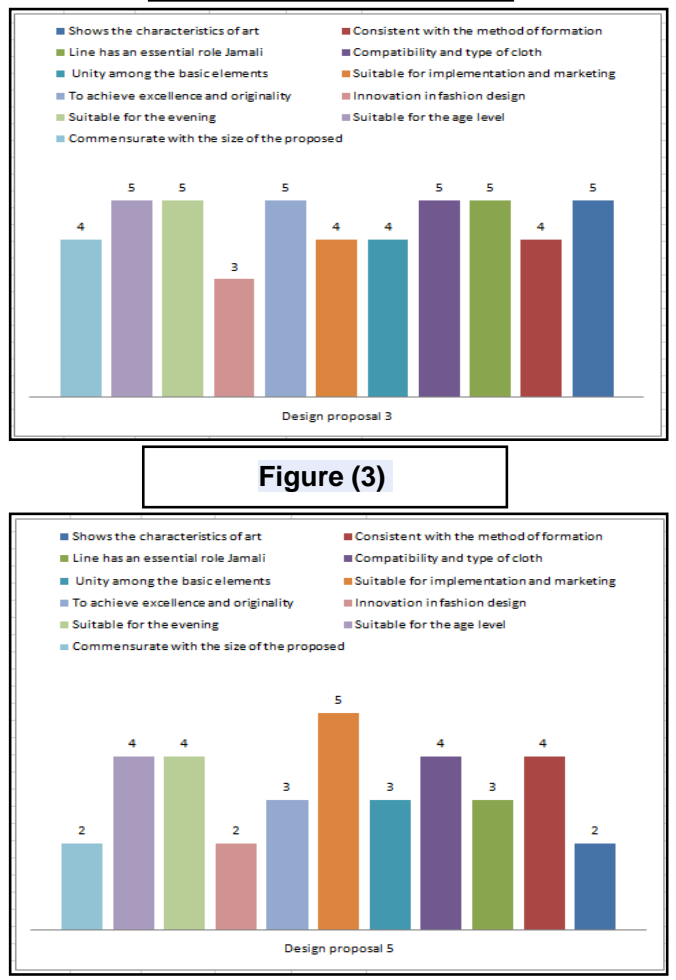

Figure (5)

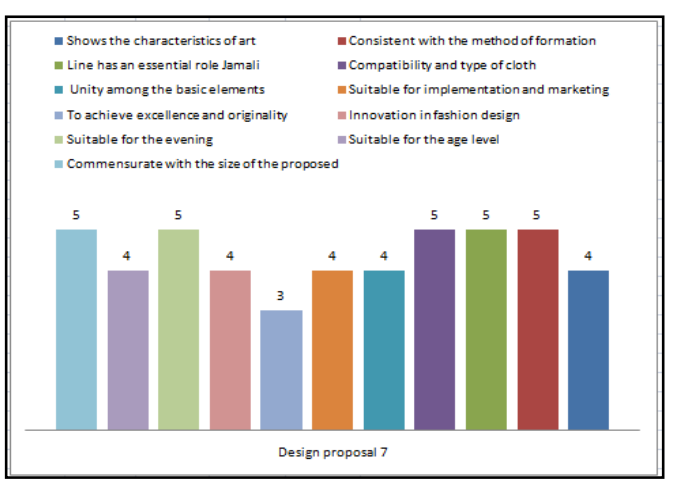

Figure (7)
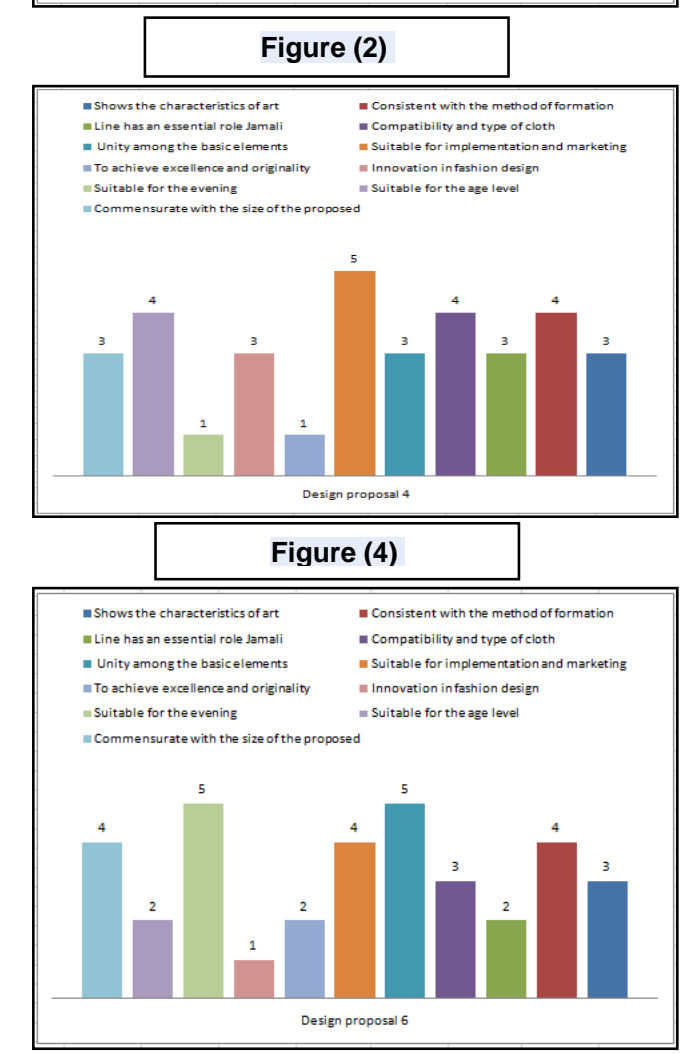

Figure (6)

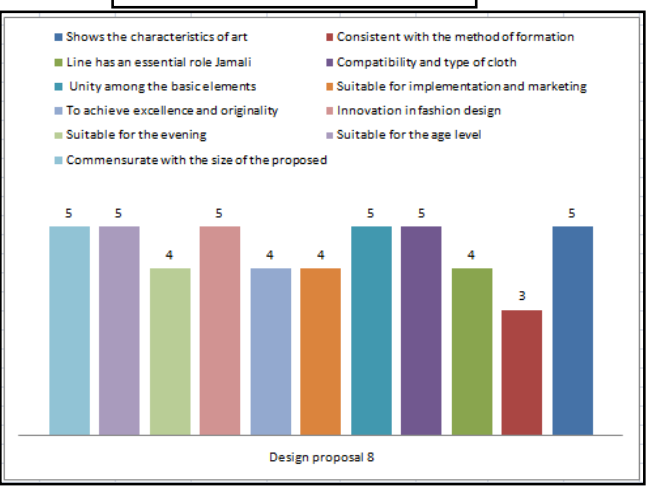

Figure (8) 


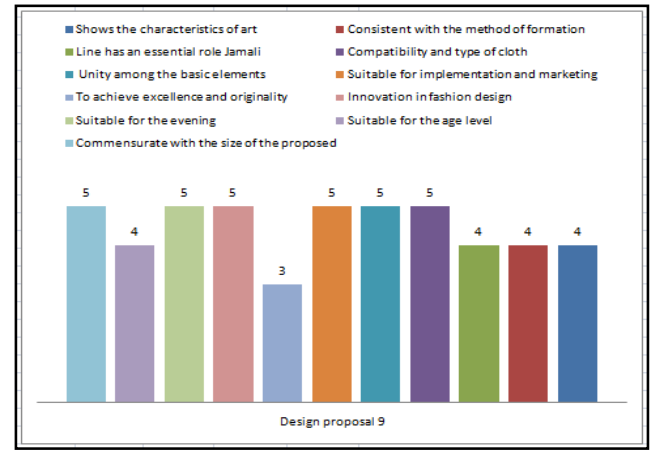

Figure (9)

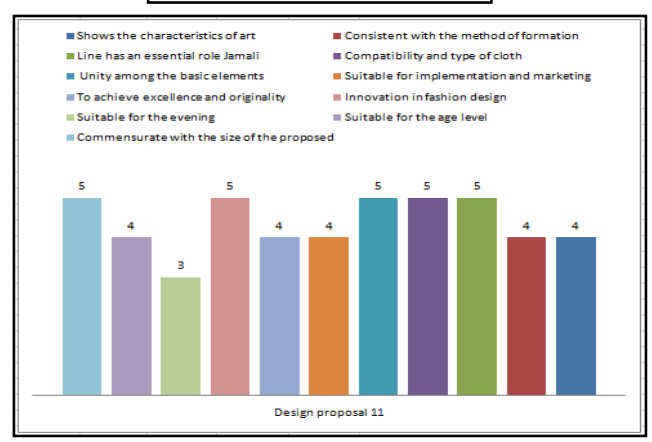

Figure (11)

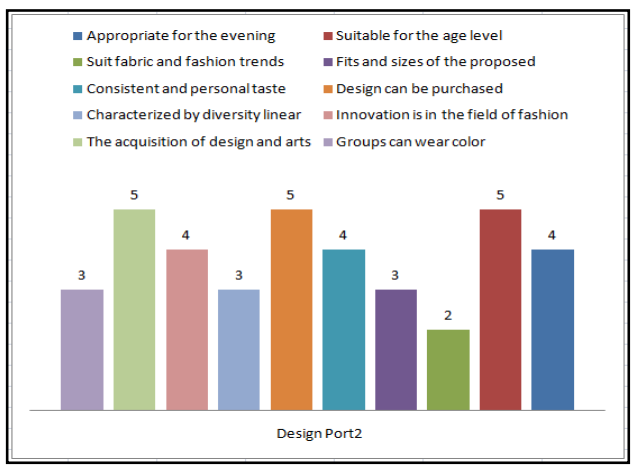

Figure (13)

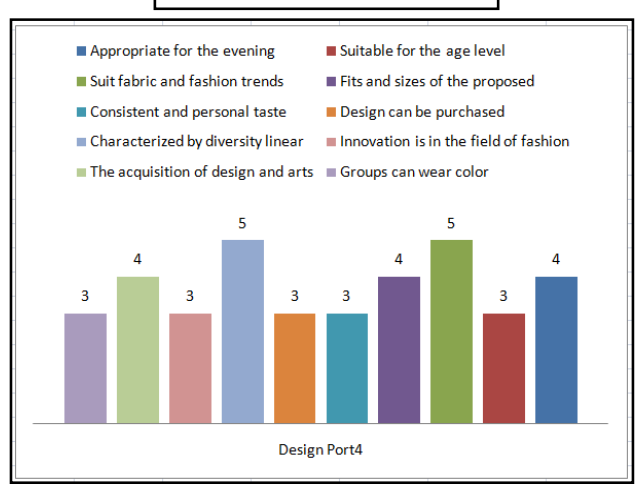

Figure (15)

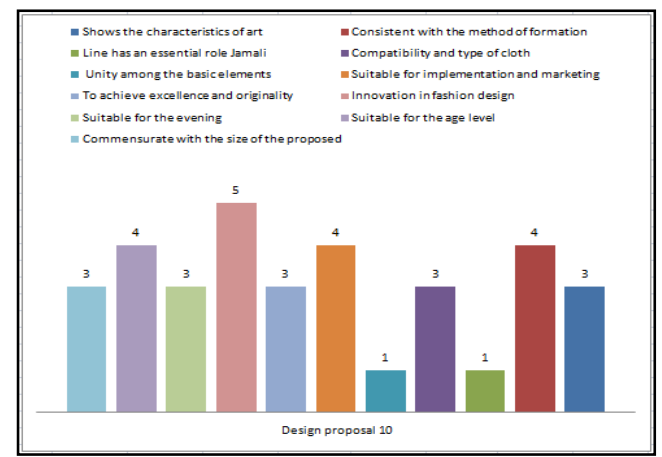

Figure (10)

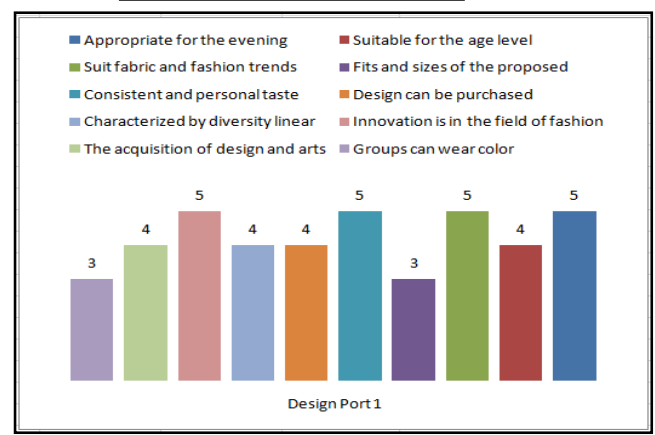

Figure (12)

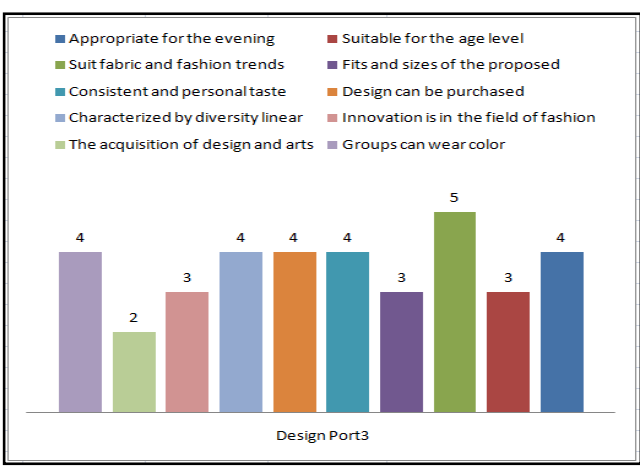

Figure (14)

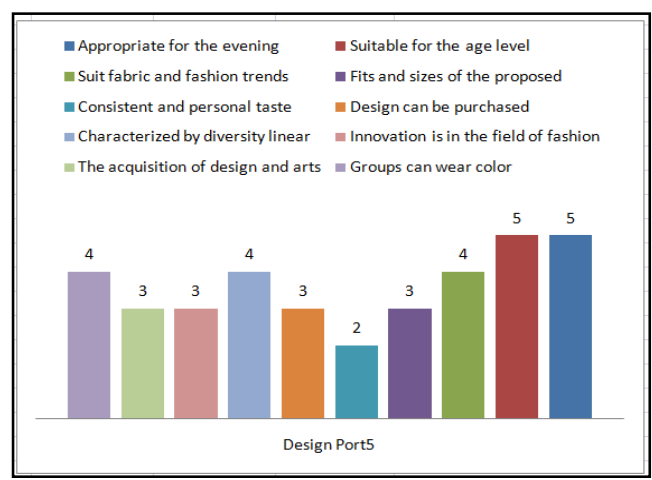

Figure (16) 


\section{Thirdly analysis the statistical results :}

First : Regarding the questionnaire related with the specialized or the producers of the suggested designs that resulted in the following results " Figure 1 to $11 "$ :-

1- Regarding the statement of ( That the design shows some traits of the art of therapy ) by which the design achieved the percent of 3,4, 7,9 which is the highest marks .

2- Regarding the statement of ( The design copes with the style of the applied shaping ) by which the design achieved the percent of 7,9,11 which is the highest marks .

3- The statement of ( The line has its aesthetical main role in the design ) is that the design has achieved the rate of 3,7,8,9,11the highest degrees of evaluation.

4- The statement of ( The design aschieved cakind of unity between its basic elements - the line - the color - the material and the shape ) and that the design has achieved the rates of $8,9,11,6$ which is the highest degrees of evaluation.

5- Then the statement of ( That the design can be suitable for being applied and marketed) the design achieved the rates of 2,3,1 which are the highest degrees of the evaluation.

6- The statement of ( That the design is suitable for the innovation in the field of designing the clothes ) the design has achieved the rates or the degrees of 9,11,8 which are the highest degrees for evaluation .

7- Regarding the statement of ( It is suitable for the evening period ) the design achieved the degrees of 6,7,9,3 which are the highest degrees for evaluation.

8- Regarding the statement that ( The design is suitable for the girls of 18-21) so the design has achieved the rate or the degrees of $8,9,11,7$ which are the highest marks in the evaluation .

Secondly : The results of the questionnaire form related with the consumed applied designs they were as the following "Figure 12 to 16 " :-

1- Regarding the statement of (the design suits the after noon period) the design has achieved 1,5 the highest degrees of evaluation.

2- The statement (it is suitable for the girl in the age of 18-21) so the design achieved the rate or the degrees of 2,5. which are the highest marks in the evaluation .

3- The statement that the material or the clothes can suit the trends of the fashion, so the design achieved the rate or the degrees of 5,3,1 which are the highest marks in evaluation. 
4- The statement that the suggested design suits the sizes from 38 to 42 the design achieved the rate or the degrees of 4 which are the highest of evaluation.

5- The statement that the design suits the personnel taste so the design achieved 1 which is the highest degree in the evaluation .

6- The statement of that is possible for me to buy the design and wear it so the degree which is the highest for the evaluation .

7- The statement that the variation of the linear gives distinction to the design - the design achieved 4 which is the highest degrees in the evaluation .

8- The statement that the suggested design is regarded as innovation in the field of the clothes so the design achieved 1 which is the highest in the degrees of the evaluation.

9- The statement of that I like to have the design expresses the fine arts - so the design achieved the highest degrees which is 2 for the evaluation.

10-Lastly the statement that it is possible for me to wear the design if it was applied by another group of colors so the design has achieved the rate or the degree of 3,4 which is the highest marks in the evaluation .

\section{Recommendations :}

1- The effectiveness of the fine arts role especially the photographic art through the deepening in his study and utilizing it in designing the clothes.

2- Deepening in the study of the Egyptian photography its development through the ages to design clothes that gather between the old and the new .

3- The trial to link between the scientific research the fine arts field - fashion design field and the modeling on the dress form.

\section{References :}

1. Samir Mahmoud, photographers technical groups in Egypt during the forties, MA , College of Fine Arts , Helwan Univ., 1997.

2. Izz al-Din Najib, dawn of modern Egyptian photography, Future House, Cairo, 1980.

3. Kamal Aljowaily, Our art is contemporary , Journal of Contemporary Thought, Cairo, April number 5,1996.

4. Mohamed Salem, Entrance to the contemporary Egyptian art, Master , Faculty of Fine Arts , Alexandria, 1993.

5. Mohamed Ibrahim Mohamed, Impact of modern art galleries on the West the work of some leading Egyptian Painting comparative analysis of application-specific designs printed upholstery fabrics , $\mathrm{PhD}$, College of Applied Arts , Helwan Univ. , 2003. 
6. Mohamed Ezzat Mostafa, Session Art, House of the Arab Thought, Cairo, 1997.

7. Naim Ateya, Art and avant-garde pioneers of enlightenment in Egypt, the Egyptian General Book Organization, Cairo, 1996.

8. Naim Ateya, Modern art to try to understand, House of knowledge, Cairo , 1982.

الإستفادة من القيم الجمالية لعنصر الخط في أعمال الفنان المصري

" عبد الوهاب عبد المحسن " لتصميم أزياء السهرة بأسلوب التشكيل على المانيكان

$$
\begin{aligned}
& \text { د / نيرمين عبد الرجـــــمن عبد الباسط } \\
& \text { أستاذ مساعد بقسم الملابس والنسيج } \\
& \text { كلية الإقتصاد المنزلي - جامعة حلوان }
\end{aligned}
$$

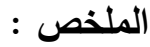

تعدت مذاهب الفنون التشكيلية وأصبح كل فنان تتكيلي يبحث عن أسلوب يميزه عن غيره ، ويتتاول

البحث أحد الفنانين التشكيلين المتميزين وهو الفنان عبد الوهاب عبد المحسن ، وقامت لفئ الباحثة بالتعريف

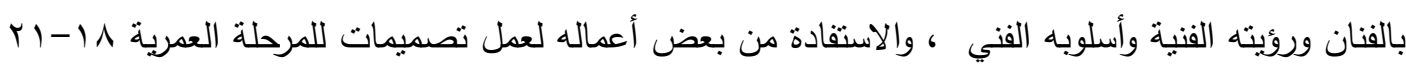
سنة وذلك باستخدام التشكيل علي المانيكان ، وتقييم هذه التصميمات من المتخصصين والمستهلكين ولهين لمعرفة

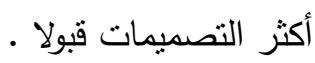

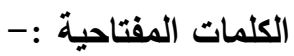

القيم الجمالية ، الخط ، تصميم أزياء ، تتكيل على المانيكان • 